\title{
Seasonal Differences in Plankton Community and Removal Efficiency of Nutrients and Organic Matter in a Subtropical Constructed Wetland
}

\author{
Fernanda Travaini-Lima $^{1}$ - Ana Milstein ${ }^{2}$ - Lúcia Helena Sipaúba-Tavares ${ }^{1}$
}

Received: 16 February 2015 /Accepted: 28 July 2016 /Published online: 25 August 2016

(C) Society of Wetland Scientists 2016

\begin{abstract}
The performance of free water surface flow constructed wetlands (CW) may be impaired by abiotic factors. The effects of seasons on the water quality improvement and on the community of plankton were evaluated in a CW system with the macrophytes Cyperus giganteus Vahl, Typha domingensis Pers., Eichhornia crassipes (Mart.) Solms and Pontederia cordata L. Water, plankton and macrophytes were sampled in the inflow and outflow during the dry and rainy seasons. Differences in temperature, precipitation, hydraulic loading rate (HLR), hydraulic retention time (HRT), inlet mass loadings and plant biomass between seasons affected the treatment efficiency. High precipitation and the consequent increase in HLR along with an increase in temperature and lower macrophyte biomass, were correlated to lower rates of removal efficiency during the rainy season. The season with higher macrophytes abundance coincided with high retention of zooplankton and solids. Higher nutrient levels in the dry season corresponded with a dominance and abundance of $r$ strategist planktonic species. To increase the removal efficiency of nutrients and organic matter by $\mathrm{CW}$ systems, care should be taken to decrease the HLR especially in periods of high precipitation.
\end{abstract}

Fernanda Travaini-Lima travaini.lima@gmail.com

1 Limnology and Plankton Production Laboratory, Aquaculture Center, São Paulo State University (UNESP), Jaboticabal, São Paulo 14884-900, Brazil

2 Agricultural Research Organization (ARO), Fish \& Aquaculture Research Station Dor, M.P. Hof HaCarmel 30820, Israel
Keywords Biological treatment · Phytoplankton · Zooplankton $\cdot$ Species richness $\cdot$ Species diversity $\cdot$ Annual cycles

\section{Introduction}

Constructed wetlands (CW) are low cost easily maintained systems. As such, they may be the best alternative for the treatment of effluents in developing countries with serious water eutrophication problems (Baptista et al. 2008; Li et al. 2008). Several abiotic factors, such as water availability (Mann and Wetzel 2000), sediment quality (Kim et al. 2001), temperature, water level fluctuations (Ellery et al. 2003) and hydraulic loading rate (Travaini-Lima and SipaúbaTavares 2012) affect the operational efficiency of constructed wetland systems. Plants are highly important during the treatment since $\mathrm{CW}$ with macrophytes are more efficient in nitrogen, phosphorus, $\mathrm{BOD}_{5}$, solids and thermotolerant coliforms removal than systems without any vegetation (Chung et al. 2008; Maltais-Landry et al. 2009).

Macrophytes in $\mathrm{CW}$ also have a strong influence on the structure and dynamics of the planktonic community, playing an important role in the complex interactions that occur in CW systems (Sinistro et al. 2006). The coverage of macrophytes is a major factor in the occurrence of phytoplankton species in wetlands, because they strongly modify the light conditions. Phytoplankton needs light and nutrients for photosynthetic production, and the availability of these factors directly influences the density and composition of the community (Izaguirre et al. 2001; O'Farrell et al. 2003; Izaguirre et al. 2004). The aquatic vegetation also affects the feeding habits of different species of the zooplankton community, as well as the size structure of zooplankton populations because macrophytes provide an important refuge area for these organisms 
(Lansac-Tôha et al. 2003). Many studies (Jeppesen et al. 1998; Van Donk and Van de Bund 2002; Norlin et al. 2005) have evaluated the role of zooplankton trophic interactions in submerged plants, but the number of studies of these interactions in floating and emergent macrophytes is limited (Bobbink et al. 2008).

Hydrologic processes are closely tied to wetland ecology and are typically highly variable in space and time (Mitsch and Gosselink 2000), especially in sub-tropical regions where rainfall influence on the hydrologic processes changes with season. Wastewater composition in these areas varies throughout the year, according to the dry and rainy seasons (Trang et al. 2010). Management recommendations developed in temperate wetlands may not be directly applicable to humid tropical and subtropical areas because of extreme hydrological inputs e.g., high annual precipitation, and dissimilar processes and interactions among ecosystem components (Kaplan et al. 2011).

The objectives of this research were to: (1) estimate the potential of a subtropical free water surface flow $\mathrm{CW}$ system to remove incoming nutrients and organic matter during the rainy and dry seasons; and (2) study the spatial and temporal variations of planktonic organisms in the $\mathrm{CW}$ system and their relationships to possible limiting factors in the ecosystem.

\section{Materials and Methods}

\section{Study Area and Sampling Sites}

The CW system was built to treat the effluents of the Aquaculture Center of São Paulo State University (UNESP), southeast Brazil $\left(21^{\circ} 15^{\prime} \mathrm{S}\right.$ and $48^{\circ} 18^{\prime} \mathrm{W}$ ) (Fig. 1a). Daily means of meteorological conditions during the summer rainy season (December 2009 to March 2010) were: $24.2 \pm 1.4{ }^{\circ} \mathrm{C}$ air temperature, $26.9 \pm 0.8{ }^{\circ} \mathrm{C}$ water temperature and $16.4 \pm 19.5 \mathrm{~mm}$ rainfall, while during the winter dry season (June to August 2009) the daily means were $20.3 \pm 2.4{ }^{\circ} \mathrm{C}$, $21 \pm 0.9^{\circ} \mathrm{C}$ and $0.06 \pm 0.2 \mathrm{~mm}$ respectively.

These effluents originated from six earthen ponds at the Aquaculture Center with areas varying between 1822 and $8067 \mathrm{~m}^{2}$ (Fig. 1b). Some of these ponds received water from other smaller earthen ponds located further up the watershed. The CW system also treats effluents originated in a series of Upflow Anaerobic Sludge Blanket reactors (UASB) with volumes ranging between 50 and $908 \mathrm{~L}$. During this study, the effluent used to feed the UASB reactors was swine manure.

The CW system has an area of $96.6 \mathrm{~m}^{2}$ and is $71 \mathrm{~m}$ long, mean width of $1.36 \mathrm{~m}$, shallow, and has a clayey bottom (Fig. 1c). At the beginning of both the rainy season and the dry season, the $\mathrm{CW}$ system was planted with four macrophyte species: Cyperus giganteus Vahl $\left(20 \mathrm{~m}^{2}\right)$, Typha domingensis Pers. $\left(13 \mathrm{~m}^{2}\right)$, Eichhornia crassipes (Mart.) Solms $\left(10 \mathrm{~m}^{2}\right)$ and Pontederia cordata L. $\left(3 \mathrm{~m}^{2}\right)$. Immediately after plant transplantation, the $\mathrm{CW}$ system was filled to a depth of approximately $0.30 \mathrm{~m}$ with a continuous water flow. The CW system receives the wastewaters of the aquaculture farm and UASB system through two concrete pipes in a spring box, allowing the entrance of water in a wide and uniform way. The wastewater, after passing through the $\mathrm{CW}$ system, is collected in another spring box and discharged into the Jaboticabal stream.

In each season the initial sampling of water and plankton started 1 month after the plants had been transplanted and wastewater loading began. At that time, the macrophyte biomass densely covered the designated area. Samples were collected at the inlet site (WI) of the CW system in the output of the influent spring box, and at the outlet site (WO) in the input of the effluent spring box (Fig. 1c). Collection was performed once a week in the early morning during the dry season (June to August 2009) and biweekly during the rainy season (December 2009 to March 2010). In the rainy season the sampling frequency was lower because the sample collection should happen after a rain event of at least 2 days. Water samples were collected in polyethylene bottles $(500 \mathrm{ml})$ and stored at $-20^{\circ} \mathrm{C}$ for later nutrients quantification.

Biomass of aquatic macrophytes was monitored during the experimental period. All the macrophyte materials in a quadrat of $0.13 \mathrm{~m}^{2}$ were harvested in triplicate and washed in the laboratory, at the end of the rainy (March) and the dry (August) seasons. The above and underground tissues were not separated, and the plants were dried to a constant weight in a fan forced oven at $60{ }^{\circ} \mathrm{C}$ until weight stabilization given by complete dehydration.

\section{Laboratory Analyses}

Water and plankton were sampled at $0.10 \mathrm{~m}$ under the water surface. Conductivity (Cond), $\mathrm{pH}$ and temperature $\left({ }^{\circ} \mathrm{C}\right)$ were measured using a Horiba multi-probe (model U-10, Horiba $\mathrm{Co}$ ), and dissolved oxygen (DO) was measured with a portable YSI oxygen meter (model 55, Yellow Spring Instr). Total suspended solids (TSS), total dissolved solids (TDS) and 5day biochemical oxygen demand $\left(\mathrm{BOD}_{5}\right)$ were determined according to Boyd and Tucker (1992). Nitrate $\left(\mathrm{NO}_{3}\right)$, nitrite $\left(\mathrm{NO}_{2}\right)$, total phosphorus (TP) and soluble reactive phosphorus (SRP) were measured following Golterman et al. (1978) and ammonia $\left(\mathrm{NH}_{4}\right)$ was measured following Koroleff (1976). Chlorophyll-a (Chl-a) and thermotolerant coliforms (TC) were determined following Nusch (1980) and Greenberg et al. (1992), respectively. Analyses were performed immediately after sampling or samples were correctly stored under refrigeration until analyzed.

For zooplankton, $10 \mathrm{~L}$ of water were filtered through a net of $58 \mu \mathrm{m}$ pore-size and concentrated to $50 \mathrm{ml}$. Formalin was added to reach $4 \%$ final concentration. Cladocera and 
Fig. 1 Geographic location (a) and layout of the Aquaculture Center (b) and of the constructed wetland system $(\mathbf{c})$, where $\mathrm{WI}=$ water inlet; $\mathrm{WO}=$ water outlet; $\mathrm{Cg}=$ Cyperus giganteus; $\mathrm{Td}=$ Typha domingensis; $\mathrm{Ec}=$ Eichhornia crassipes; $\mathrm{Pc}=$ Pontederia cordata

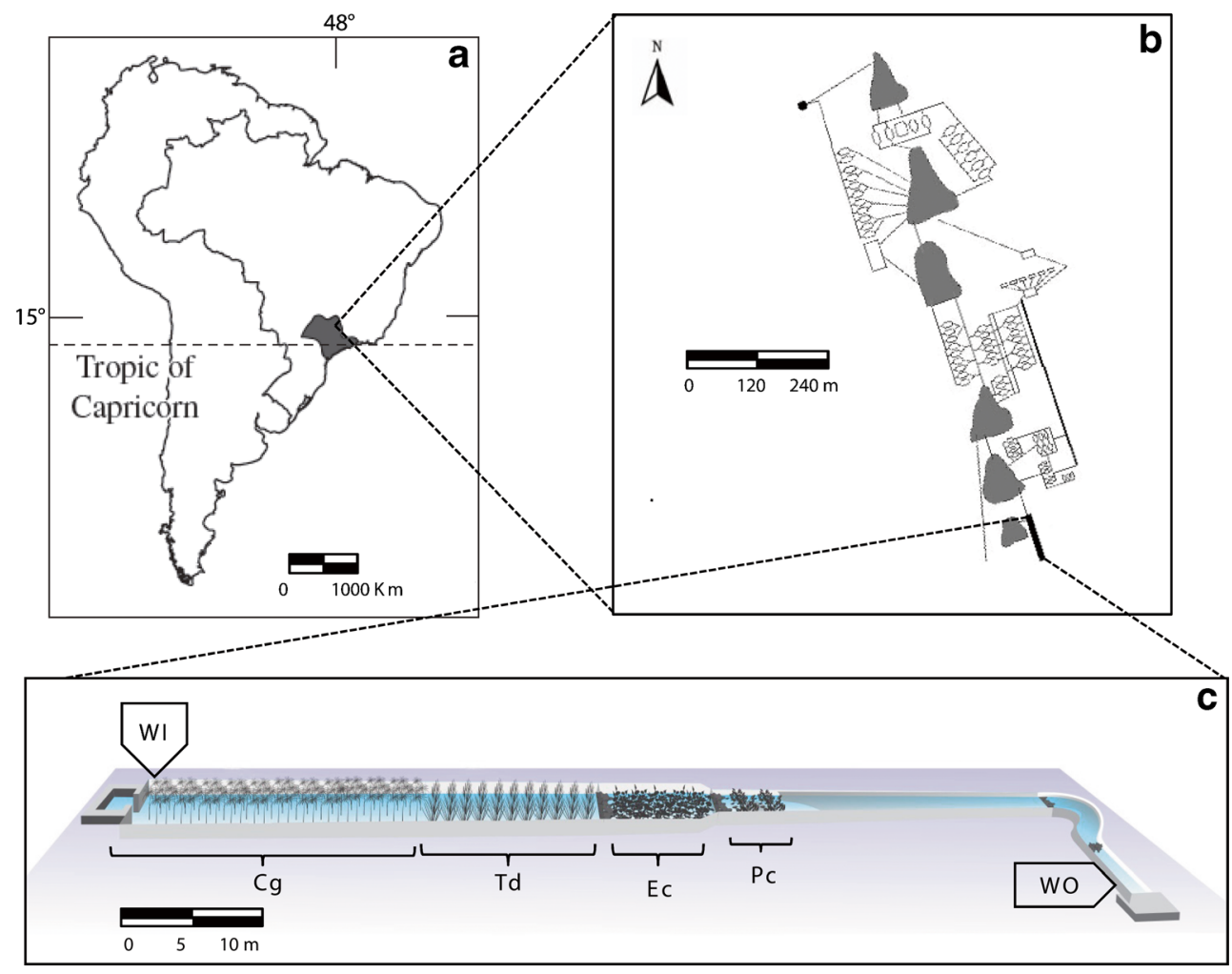

Copepoda were identified in a reticulated acrylic chamber under stereomicroscope (40 $\times$ augmentation). Rotifera were identified and counted in a Sedgewick-Rafter chamber under a Leitz microscope $(100 \times$ augmentation). Phytoplankton samples were collected with polyethylene bottles and preserved with Lugol $1 \%$ solution. Phytoplankton abundance was estimated by counting the cells according to Utermöhl (1958) using sedimentation chambers following recommendations in Lund et al. (1958). Phytoplankton counting was carried out in an inverted microscope Axiovert 40 CFL (Carl Zeiss).

\section{Constructed Wetland Hydraulic and Wastewater Loading}

The hydraulic loading rate (HLR) of the CW system was calculated for the dry and rainy seasons as

$q=\frac{Q}{A}$,

where $q$ is the HLR $\left(\mathrm{m} \mathrm{h}^{-1}\right) ; Q$ is the water inlet rate $\left(\mathrm{m}^{3} \mathrm{~h}^{-1}\right)$ and $A$ is the wetland land area $\left(\mathrm{m}^{2}\right.$ ) (Kadlec and Wallace 2009). $Q$ was measured manually using a calibrated bucket and stopwatch. The hydraulic retention time (HRT) for the two seasons were measured as

$H R T=\frac{V}{Q}$,

in hours (h); $V$ is the maximum volume of the canal $\left(\mathrm{m}^{3}\right)$ and $Q$ is the water inlet rate $\left(\mathrm{m}^{3} \mathrm{~h}^{-1}\right)$. The mass loading rate of each physical and chemical parameter was calculated separately for the inlet and outlet in each season as

$m=q \times C$,

where $m$ is the (specific) mass loading $\left(\mathrm{g} \mathrm{m}^{-2} \mathrm{~d}^{-1}\right) ; q$ is the HLR $\left(\mathrm{m} \mathrm{h}^{-1}\right)$ and $C$ is the concentration $\left(\mathrm{g} \mathrm{m}^{-3}\right)$. The removal efficiency (RE \%) of mass loads by the CW system was measured by the formula

$\mathrm{RE} \%=\frac{m_{i}-m_{o}}{m_{i}} \times 100$,

where $m_{i}$ is the mass load in the inlet $\left(\mathrm{g} \mathrm{m}^{-2} \mathrm{~d}^{-1}\right)$ and $m_{o}$ is the mass load in the outlet $\left(\mathrm{g} \mathrm{m}^{-2} \mathrm{~d}^{-1}\right)$.

\section{Data Analysis}

Two-way ANOVA was used to evaluate interactions between seasons and inlet/outlet $\mathrm{CW}$ effects of the hydrological and physico-chemical parameters and plankton community. Phytoplankton and zooplankton abundances were $\log 10$ transformed $(\log (\mathrm{x}+1))$ to normalize the data and reduce the sample variance. For the macrophyte species, statistical comparisons between seasons and between species in each season were performed with one-way ANOVA. When significant differences were detected, the Fisher LSD test was used for post-hoc comparisons. The statistical analyses were carried out with Statistica 8.0 (StatSoft 2007) and were done at $P=0.05$. 
The relationships among the plankton, sampling sites and water quality were investigated using canonical correspondence analysis (CCA) (ter Braak 1988). Monte Carlo test was applied in order to verify the probability of the eigenvalues of the ordination axes having been randomly attributed (999 iterations; $P=0.05$ ). The CCA was carried out with PCORD 5.15 (McCune and Mefford 2006).

Zooplankton and phytoplankton diversity were calculated at each site using the Shannon-Wiener (H') formula (Pielou 1975). Richness (S) was calculated as the total number of species present at each sampling site. Evenness or equitability (E) was calculated as $\mathrm{H} / \mathrm{H} \max$, where $\mathrm{H}$ is the ShannonWiener index and $\mathrm{H}$ max $=\ln \mathrm{S}$.

The analyses of dominance and abundance of species were performed for phytoplankton and zooplankton. A species was considered dominant when its density was higher than $50 \%$ of the total number of individuals present, and abundant when the number of individuals was higher than the mean density of all occurring species (Lobo and Leighton 1986).

\section{Results}

\section{Water Quality}

The CW system had significantly higher mean HLR in the rainy season $\left(0.57 \mathrm{~m} \mathrm{~h}^{-1}\right)$ than in the dry one $\left(0.32 \mathrm{~m} \mathrm{~h}^{-1}\right)$, whereas, the mean HRT was significantly higher in the dry season $(3 \mathrm{~h} 23 \mathrm{~min})$ than in the rainy one $(2 \mathrm{~h} 47 \mathrm{~min})$. For the calculations, the increase of HLR during the rainy season was attributed only to an increase in waste loading from the aquaculture system, because the measures of rainfall and runoff were not taken. It was observed that in the rainy season the depth of CW system increased, being approximately $0.60 \mathrm{~m}$ in the WI and $0.50 \mathrm{~m}$ in the WO, whereas in the dry season, the depth was approximately $0.30 \mathrm{~m}$ in the WI and $0.10 \mathrm{~m}$ in the WO.

The concentrations (Fig. 2) and mass loading means (Table 1) of the parameters studied were higher in the rainy season, when HLR was higher. The differences between the means of mass loadings in CW sampling sites depend on the season, as indicated by the significant $(p<0.05)$ season-site interaction effects of the two-way-ANOVAs. The nutrients $\left(\mathrm{NO}_{3}, \mathrm{NO}_{2}, \mathrm{NH}_{4}, \mathrm{SRP}\right.$ and TP) mass loadings were significantly lower in the WI during the rainy than during the dry season, due to the dilution effect from the higher HLR. The increase of water flow rate in the rainy season carried more solids (TSS) and organic matter $\left(\mathrm{BOD}_{5}\right)$ mass loadings to the effluent entering the $\mathrm{CW}$. The removal of particles, chemical species and thermotolerant coliforms was more efficient in the dry season than in the rainy one. While the removal rates for 10 variables were 77-99 \% in the dry season, they were only $47-68 \%$ in the rainy season. With removal rates lower than
$55 \%\left(\mathrm{NO}_{2}, \mathrm{NH}_{4}, \mathrm{SRP}, \mathrm{TP}\right.$ and $\mathrm{TC}$ during rainy season) the decrease of mass loadings from the WI to the WO was not significant $(p>0.05)$.

The DO was higher in the outlet sampling site than in the inlet one in the rainy season. Dissolved oxygen and $\mathrm{pH}$ were higher in the dry season than the rainy one, mainly in the WI sampling site $(p<0.05)$ (Table 1$)$. The concentrations of TP, $\mathrm{SRP}, \mathrm{BOD}_{5}, \mathrm{NO}_{2}, \mathrm{NH}_{4}$, TSS, TDS and Chlorophyll-a were higher in the inlet sampling sites than in the outlet ones in both seasons (Fig. 2). In general, the CW system had higher organic loading and lower oxygen in the water entering the system than in the water leaving it.

\section{Aquatic Macrophytes}

Few specimens of $P$. cordata survived until the end of the dry season. Although the CW system was restarted before the rainy season, all $P$. cordata disappeared before the end of this period. All the other species had a significantly larger biomass during the dry than the rainy season. Emergent species had significantly larger biomass, mainly the $C$. giganteus (Table 2).

\section{Plankton}

The phytoplankton community comprised Cyanobacteria (10 species from 7 genera), Chlorophyceae (13 species from 11 genera), Zygnemaphyceae (3 species from 2 genera), Euglenophyceae (1 species), Bacillariophyceae (9 species from 7 genera) and Xanthophyceae (1 species) (Table 3). No phytoplankton group presented significant differences between seasons, sampling sites or interaction (Table 4). During the dry season over $70 \%$ of the phytoplankton community were Chlorophyceae (mainly Kirchneriella lunaris) and the next abundant groups were Bacillariophyceae and Cyanobacteria; during the rainy season Bacillariophyceae and Chlorophyceae each formed about $40 \%$ of the phytoplankton, the remaining $20 \%$ being mostly Cyanobacteria (Fig. 3a). In both seasons phytoplankton species richness was high (above 27 species), while evenness values and species diversity index were higher in the rainy season $(p<0.05)$ (Table 4).

The zooplankton community comprised Rotifera (31 species from 17 genera), Cyclopoida Copepoda (1 species), Calanoida Copepoda (1 species) and Cladocera (4 species). Rotifera were the dominant group (above $97 \%$ ) in both seasons and sampling sites. The ANOVAs of zooplankton groups showed significant $(p<0.01)$ interactions between seasons and $\mathrm{CW}$ sampling sites, indicating that the differences in the abundances of zooplankton groups in the CW sampling sites depend on seasons. Copepoda in the WI were more abundant during the rainy than during the dry season (Fig. 3b, Table 4). Density of all zooplankton groups was only significantly 

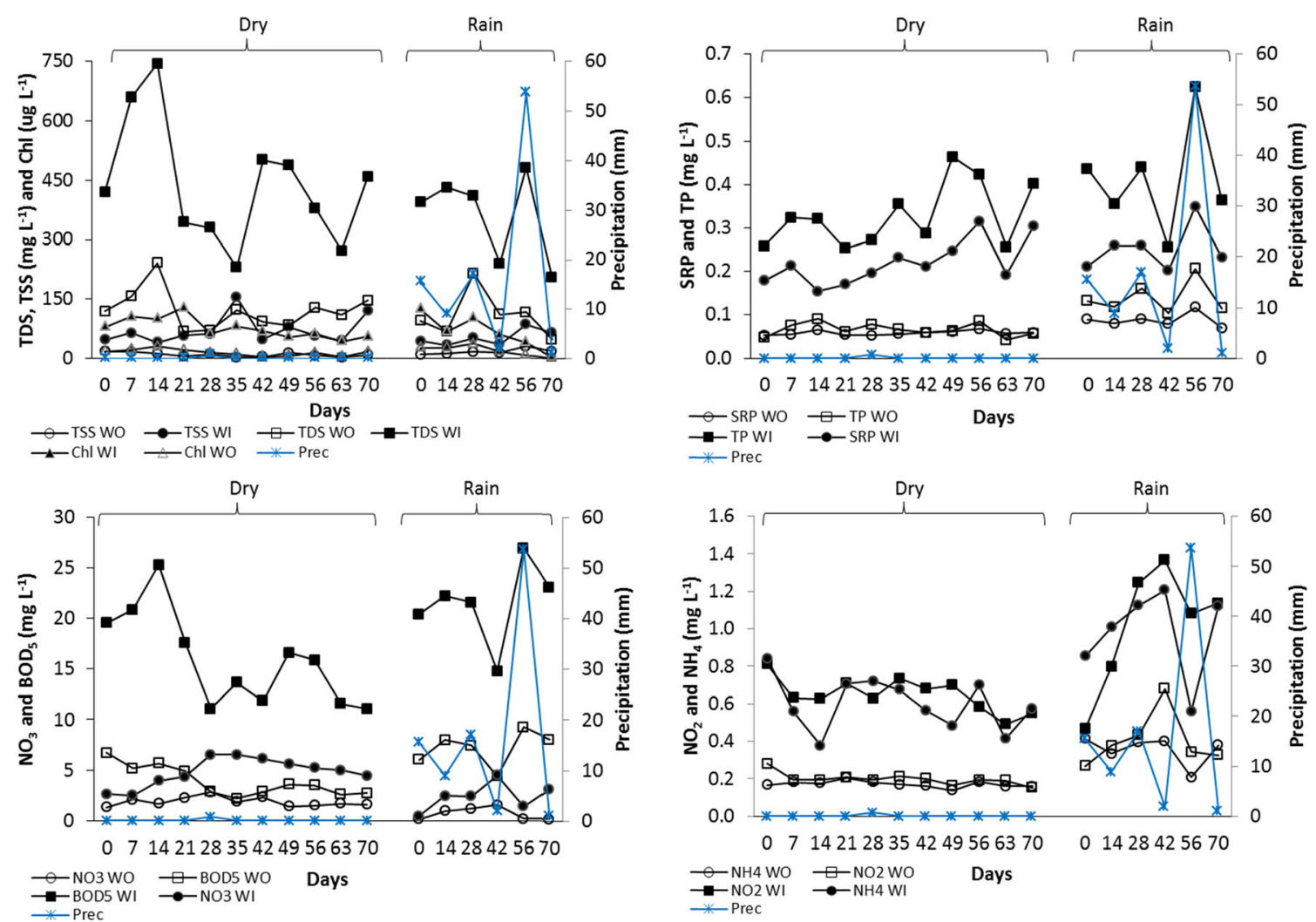

Fig. 2 Concentrations of Chlorophyll-a $\left(\mu \mathrm{g} \mathrm{L}^{-1}\right)$, solids and nutrients $\left(\mathrm{mg} \mathrm{L}^{-1}\right)$ in the $\mathrm{CW}$ system at the water inlet (WI) and water outlet (WO) in the dry and rainy seasons, against time (days), with a daily precipitation line $(\mathrm{mm})$ included

lower in the WO sampling site during the dry season. The densities of Cladocera and Copepoda in the WO were lower during the dry than during the rainy season. The $\mathrm{CW}$ system tended to have high zooplankton species richness (above 22 species), evenness (above 0.78) and diversity (ShannonWiener index between 2.47 and 2.76 nats ind $^{-1}$ ) (Table 4).
Table 1 Mean and standard deviation of $\mathrm{pH}$, conductivity $\left(\mu \mathrm{S} \mathrm{cm}{ }^{-1}\right)$, DO (mg L $\left.{ }^{-1}\right)$, mass loading of physical and chemical parameters $\left(\mathrm{g} \mathrm{m}^{-2} \mathrm{~d}^{-1}\right)$, most probable number and standard deviation (MPN $10^{3}$
$100 \mathrm{ml}^{-1}$ ) of thermotolerant coliforms, and removal efficiency rates (RE $\%$ ) in the water inlet (WI) and outlet (WO) of CW system for each season, and ANOVA results for all parameters

\begin{tabular}{|c|c|c|c|c|c|c|}
\hline & \multicolumn{3}{|l|}{ Dry } & \multicolumn{3}{|l|}{ Rainy } \\
\hline & WI & WO & $\mathrm{RE} \%$ & WI & WO & RE \% \\
\hline $\mathrm{pH}$ & $6.8 \pm 1.0^{\mathrm{a}}$ & $6.9 \pm 1.0^{\mathrm{a}}$ & - & $5.9 \pm 0.4^{\mathrm{b}}$ & $6.2 \pm 0.4^{\mathrm{ab}}$ & - \\
\hline Conductivity & $113.5 \pm 64.7^{\mathrm{ns}}$ & $113.7 \pm 64.3^{\mathrm{ns}}$ & - & $78.0 \pm 1.2^{\mathrm{ns}}$ & $77.2 \pm 2.3^{\mathrm{ns}}$ & - \\
\hline DO & $6.6 \pm 0.4^{\mathrm{a}}$ & $6.8 \pm 0.4^{\mathrm{a}}$ & - & $4.2 \pm 0.8^{\mathrm{c}}$ & $5.6 \pm 0.6^{\mathrm{b}}$ & - \\
\hline $\mathrm{BOD}_{5}$ & $51.7 \pm 27.9^{\mathrm{b}}$ & $8.2 \pm 4.7^{\mathrm{c}}$ & 77 & $102.6 \pm 18.8^{\mathrm{a}}$ & $42.7 \pm 15.9^{b}$ & 58 \\
\hline Nitrate & $16.0 \pm 5.4^{\mathrm{a}}$ & $3.7 \pm 1.2^{\mathrm{c}}$ & 80 & $9.5 \pm 5.6^{\mathrm{b}}$ & $3.8 \pm 3.5^{\mathrm{c}}$ & 60 \\
\hline Nitrite & $2.0 \pm 0.5^{\mathrm{a}}$ & $0.4 \pm 0.2^{\mathrm{b}}$ & 79 & $0.2 \pm 0.1^{\mathrm{bc}}$ & $0.1 \pm .0 .04^{\mathrm{c}}$ & 47 \\
\hline Ammonia & $1.6 \pm 0.4^{\mathrm{a}}$ & $0.3 \pm 0.1^{\mathrm{b}}$ & 81 & $0.2 \pm 0.1^{\mathrm{b}}$ & $0.09 \pm 0.02^{\mathrm{b}}$ & 52 \\
\hline SRP & $0.6 \pm 0.1^{\mathrm{a}}$ & $0.1 \pm 0.03^{\mathrm{b}}$ & 85 & $0.05 \pm 0.01^{\mathrm{c}}$ & $0.02 \pm 0.01^{\mathrm{c}}$ & 52 \\
\hline $\mathrm{TP}$ & $0.9 \pm 0.2^{\mathrm{a}}$ & $0.1 \pm 0.04^{\mathrm{b}}$ & 84 & $0.08 \pm 0.03^{\mathrm{b}}$ & $0.03 \pm 0.02^{\mathrm{b}}$ & 55 \\
\hline TSS & $163.3 \pm 58.9^{\mathrm{b}}$ & $20.2 \pm 15.3^{\mathrm{c}}$ & 88 & $252.7 \pm 85.8^{\mathrm{a}}$ & $106 \pm 66.2^{\mathrm{b}}$ & 58 \\
\hline TDS & $1308.7 \pm 831.5^{\mathrm{a}}$ & $243.0 \pm 99.8^{b}$ & 81 & $1504.3 \pm 593.8^{\mathrm{a}}$ & $641.1 \pm 328.1^{\mathrm{b}}$ & 57 \\
\hline Chlorophyll-a & $0.23 \pm 0.1^{\mathrm{a}}$ & $0.03 \pm 0.02^{\mathrm{b}}$ & 87 & $0.33 \pm 0.2^{\mathrm{a}}$ & $0.11 \pm 0.1^{\mathrm{b}}$ & 68 \\
\hline Thermotolerant Coliforms & $7.4 \pm 1.8^{\mathrm{a}}$ & $0.051 \pm 0.065^{\mathrm{b}}$ & 99 & $17.6 \pm 2.9^{\mathrm{a}}$ & $9.4 \pm 1.3^{\mathrm{a}}$ & 47 \\
\hline
\end{tabular}

In each row, means followed by the same letter do not differ $(p<0.05)$; $n s$ not significant difference, - not applicable 
Table 2 Mean biomass and results of one-way ANOVA of the macrophytes during the dry and rainy seasons

\begin{tabular}{llll}
\hline Biomass $\left(\mathrm{g} \mathrm{DW} \mathrm{m}^{-2}\right)$ & T. domingensis & C. giganteus & E. crassipes \\
\hline Dry & $2226.5^{\mathrm{a}}$ & $2244.9^{\mathrm{a}}$ & $743.4^{\mathrm{b}}$ \\
Rainy & $1372.5^{\mathrm{b}}$ & $2029.7^{\mathrm{a}}$ & $352.1^{\mathrm{c}}$ \\
ANOVA Seasons & $*$ & $*$ & $*$ \\
\hline
\end{tabular}

In each row, means followed by the same letter do not differ $(p<0.05)$;

$*$ significant difference $(p<0.05)$ between seasons

Diaphanosoma birgei was the only Cladocera species frequently encountered throughout the study period (Table 5). The Cyclopoida and Calanoida copepods, Thermocyclops decipiens and Argyrodiaptomus furcatus respectively, were absent only at the WO in the dry season. There were more abundant Rotifera species at the WI in the dry and at the WO in the rainy seasons (Table 5).

The CCA extracted two axes which explain $38 \%$ of the overall variance in plankton data (Fig. 4). The speciesenvironment correlation was 0.89 for axis 1 and 0.85 for axis 2 indicating a strong relationship between the plankton distribution and the environmental variables used for the ordination. Monte Carlo's permutation test revealed that the ordination on axes 1 and 2 was statistically significant $(p<0.05)$. The first axis ( $24 \%$ of the variance in plankton data) presents high positive association among TP, SRP, HLR, BOD5, NO2, NH4, TSS, TDS, Water temperature $\left({ }^{\circ} \mathrm{C}\right)$, Chlorophyll-a, with Copepoda, Cladocera and most of the inlet sampling sites in the rainy season. All those variables were negatively related with DO, pH, Zygnemaphyceae, Chlorophyceae and most of the outlet sampling sites in the dry season. Thus, axis 1 represents a water quality gradient, with higher organic loading and lower oxygen in the water entering the system during the rainy season than in the water leaving it during the dry season. The axis 2 (14\% of the variance in plankton data) presents high association among TC, Euglenophyceae, Bacillariophyceae, Xanthophyceae, Cyanobacteria and most of the outlet sampling sites in the rainy season. All of them were negatively correlated with NO3, Rotifera and inlet sampling sites in the dry season (Fig. 4).

\section{Discussion}

Removal efficiencies in free water surface flow CW systems are influenced by several parameters related to annual cycles, such as water and air temperatures, solar radiation, humidity, rainfall, inlet pollutant concentrations, and vegetation (Kadlec 1999). Hydraulic characteristics such as the HLR and consequent HRT can also affect the treatment processes in these systems (Trang et al. 2010). The aforementioned parameters cause changes in the retention of nutrients, in the release of
Table 3 Composition and frequency of phytoplankton species in the water inlet (WI) and water outlet (WO), in the dry and rainy seasons

\begin{tabular}{ll}
\hline Taxa & Dry \\
& WI WO WI WO \\
\hline
\end{tabular}

Cyanobacteria

Aphanocapsa sp.

Chroococcus limneticus (Lemmermann)

Merismopedia sp.

Microcrocis pulchella (Werner)

Microcystis aeruginosa (Kützing) Kützing

Microcystis novacekii (Komárek) Compere

Microcystis panniformis Komárek et al.

Microcystis wesenbergi (Lemmermann)

Nostoc sp.

Sphaerocavum brasiliensis Azevedo et Sant'Anna

Chlorophyceae

Ankistrodesmus gracilis (Ralfs)

Coelastrum microporum (Nägeli) Kützing

Coelastrum reticulatum (Dangeard) Senn

Crucigenia quadrata (Morren)

Desmodesmus armatus (Chord.) Hegerv

Dictyosphaerium pulchellum (Wood)

Kirchneriella lunaris (Kirchner) Möbius

Micractinium pusillum Fresenius

Pediastrum duplex (Meyen)

Pediastrum tetras (Ehrenberg) Ralfs

Scenedesmus acutus (Reed)

Sphaerocystis sp.

Tetraedron trigonum (Nägeli) Hansgirg

Zygnemaphyceae

Closterium acutum Brébisson

Staurastrum lobatus (Börges.) Bourrely

Staurastrum sp.

Euglenophyceae

Euglena sp.

Bacillariophyceae

Aulacoseira sp.

Melosira granulata (Ehr.) Ralfs.

Melosira sp.

Melosira varians Agardh

Navicula sp.

Nitzschia amphibia (Grunow)

Pinnularia sp.

Synedra sp.

Tabellaria floculosa (Roth) Kütz.

$+++\mathrm{A}$

$++\mathrm{A} A$

$++++$

$++--$

$++++$

$++++$

$++++$

$++++$

$+++-$

$++\mathrm{A}+$

$+\quad+\quad+$

$++++$

$++++$

$+-+-$

$++++$

$++\mathrm{A}+$

D D A A

$++--$

$++++$

$+-++$

$++++$

$+-\quad-$

$++++$

$+\quad+\quad+$

$-\quad+-$

$+++$

$+\quad+\quad+$

$\mathrm{A}+\mathrm{A} \mathrm{A}$

A A A A

$-\quad+-$

$++\mathrm{A} A$

$+-+-$

$-+++$

$+++-$

$++++$

$+++\mathrm{A}$

Xanthophyceae

Isthmochloron lobulatum (Nägeli) Skuja

$+=$ presence; $-=$ absence; $A$ abundant, $D$ dominant 
Table 4 Phytoplankton and zooplankton quantitative analyses: density, species richness, evenness, and ShannonWiener diversity (H') index in the WI and WO sampling sites in each season, and ANOVA results of planktonic groups density

\begin{tabular}{|c|c|c|c|c|}
\hline & \multicolumn{2}{|l|}{ Dry } & \multicolumn{2}{|l|}{ Rainy } \\
\hline & WI & WO & WI & WO \\
\hline Zooplankton total & $454,606^{\mathrm{a}}$ & $149,074^{\mathrm{b}}$ & $460,807^{\mathrm{a}}$ & $391,706^{\mathrm{ab}}$ \\
\hline Cladocera (ind $\mathrm{L}^{-1}$ ) & $1,333^{\mathrm{a}}$ & $33^{\mathrm{b}}$ & $2,800^{\mathrm{a}}$ & $783^{\mathrm{a}}$ \\
\hline Copepoda (ind $\mathrm{L}^{-1}$ ) & $1,017^{\mathrm{b}}$ & $33^{\mathrm{c}}$ & $10,200^{\mathrm{a}}$ & $6,783^{\mathrm{ab}}$ \\
\hline Rotifera (ind $\mathrm{L}^{-1}$ ) & $452,256^{\mathrm{a}}$ & $149,008^{\mathrm{b}}$ & $447,807^{\mathrm{a}}$ & $384,140^{\mathrm{ab}}$ \\
\hline Richness & $32^{\mathrm{ns}}$ & $22^{\mathrm{ns}}$ & $28^{\mathrm{ns}}$ & $27^{\mathrm{ns}}$ \\
\hline Evenness & $0.78^{\mathrm{ns}}$ & $0.80^{\mathrm{ns}}$ & $0.82^{\mathrm{ns}}$ & $0.84^{\mathrm{ns}}$ \\
\hline$\left(\mathrm{H}^{\prime}\right)$ & $2.71^{\mathrm{ns}}$ & $2.47^{\mathrm{ns}}$ & $2.74^{\mathrm{ns}}$ & $2.76^{\mathrm{ns}}$ \\
\hline Phytoplankton total & $337,105^{\mathrm{ns}}$ & $465,085^{\mathrm{ns}}$ & $196,380^{\mathrm{ns}}$ & $184,360^{\text {ns }}$ \\
\hline Cyanobacteria (ind $\mathrm{mL}^{-1}$ ) & $21,886^{\mathrm{ns}}$ & $20,488^{\mathrm{ns}}$ & $33,215^{\mathrm{ns}}$ & $44,882^{\mathrm{ns}}$ \\
\hline Chlorophyceae (ind $\mathrm{mL}^{-1}$ ) & $247,475^{\mathrm{ns}}$ & $408,603^{\mathrm{ns}}$ & $74,360^{\mathrm{ns}}$ & $75,219^{\mathrm{ns}}$ \\
\hline Zygnemaphyceae (ind $\mathrm{mL}^{-1}$ ) & $370^{\mathrm{ns}}$ & $455^{\mathrm{ns}}$ & $337^{\mathrm{ns}}$ & $202^{\mathrm{ns}}$ \\
\hline Euglenophyceae (ind $\mathrm{mL}^{-1}$ ) & $303^{\text {ns }}$ & $135^{\mathrm{ns}}$ & $286^{\mathrm{ns}}$ & $354^{\mathrm{ns}}$ \\
\hline Bacillariophyceae (ind $\mathrm{mL}^{-1}$ ) & $67,054^{\mathrm{ns}}$ & $35,387^{\mathrm{ns}}$ & $88,165^{\mathrm{ns}}$ & $63,636^{\mathrm{ns}}$ \\
\hline Xanthophyceae (ind $\mathrm{mL}^{-1}$ ) & $17^{\mathrm{ns}}$ & $17^{\mathrm{ns}}$ & $17^{\mathrm{ns}}$ & $67^{\mathrm{ns}}$ \\
\hline Richness & $34^{\mathrm{ns}}$ & $31^{\mathrm{ns}}$ & $34^{\mathrm{ns}}$ & $27^{\mathrm{ns}}$ \\
\hline Evenness & $0.36^{\mathrm{b}}$ & $0.23^{\mathrm{b}}$ & $0.63^{\mathrm{a}}$ & $0.69^{\mathrm{a}}$ \\
\hline$\left(\mathrm{H}^{\prime}\right)$ & $1.26^{\mathrm{b}}$ & $0.79^{\mathrm{b}}$ & $2.21^{\mathrm{a}}$ & $2.27^{\mathrm{a}}$ \\
\hline
\end{tabular}

In each row, means followed by the same letter do not differ $(p<0.05) ; n s$ not significant difference chemical compounds and in biological activities of microorganisms and plants (Kadlec 1999; Kim et al. 2011). Based on the results given above, Fig. 5 presents a conceptual graphic model of the $\mathrm{CW}$ system performance in the dry and rainy seasons. The nutrients mass loading entering the $\mathrm{CW}$ system, the macrophyte biomass in it, and the HRT were high during the dry season. These factors facilitated sedimentation of particles and development of bacteria that were not washed away. As a result, the removal of nutrients and particles was efficient, leading to strong decreasing gradients between the input and output sites (mainly in nutrient mass loading). During the rainy season the rain increased the input of solids and organic matter mass loadings. This, together with the summer higher temperatures, enhanced decomposition processes in the $\mathrm{CW}$ system and account for the lower $\mathrm{pH}$ and $\mathrm{DO}$ concentration observed. Rain also increased HLR that reduced HRT, decreased nutrient mass loading through dilution, and decreased macrophyte biomass affecting fixation of the plants. The heterotrophic competition caused by higher organic matter and lesser oxygen concentration may affect the nitrification by restricting growth of nitrifying bacteria (Truu et al. 2005). Furthermore, the higher HLR may have created more anaerobic sediment conditions due to ponding. Therefore, probably the coupled nitrification-denitrification processes was inhibited, leading to lower removal efficiency rates of $\mathrm{NH}_{4}$ and $\mathrm{NO}_{2}$ than those measured in the dry season. As a result, decomposition and dilution were dominant processes in the $\mathrm{CW}$ system, and the removal of nutrients and particles was less efficient than in the dry season.

\section{Aquatic Macrophytes}

The similar-sized emergent macrophytes $C$. giganteus and T. domingensis had a higher biomass during the dry season. Typha species exhibit performance advantages when compared to smaller species (Hadad et al. 2006) such as E. crassipes. E. crassipes has a high production potential due to its vertical growth capacity, especially in high densities (Henry-Silva et al. 2008). However, E. crassipes had a lower biomass than the rooted species selected for this study, especially during the rainy season. Macrophytes act as a physical barrier that may retain particles, plankton and other microorganisms. Since the removal of suspended solids occurs mainly by physical mechanisms, such as sedimentation and filtration processes (Karathanasis et al. 2003), the larger plant biomass during the dry season worked as a physical barrier for TSS. Moreover the higher HRT favored the sedimentation process. Furthermore, the reduction of thermotolerant coliforms depends on sedimentation, solar radiation and inactivation by vegetation (Boutilier et al. 2009), processes that were favored during this season and caused higher TC removal rates. Submerged structures of macrophytes such as leaves, stems and roots also provide a substrate for the epiphyton development (composed of algae, debris, bacteria and other microorganisms and invertebrates), which represents an important food source for zooplanktonic Cladocera and Copepoda (Thomaz and Cunha 2010). Zooplankton may also benefit from the density of aquatic plants as refuge against possible predators mainly in more structurally complex plants that 
Fig. 3 Phytoplankton (a) and zooplankton (b) relative abundances (\%) in the CW system at the water inlet (WI) and water outlet (WO) in the dry and rainy seasons, where

Bac $=$ Bacillariophyceae;

$\mathrm{Chl}=$ Chlorophyceae;

Cya $=$ Cyanobacteria;

Eug = Euglenophyceae;

Xan = Xanthophyceae;

Zyg $=$ Zygnemaphyceae
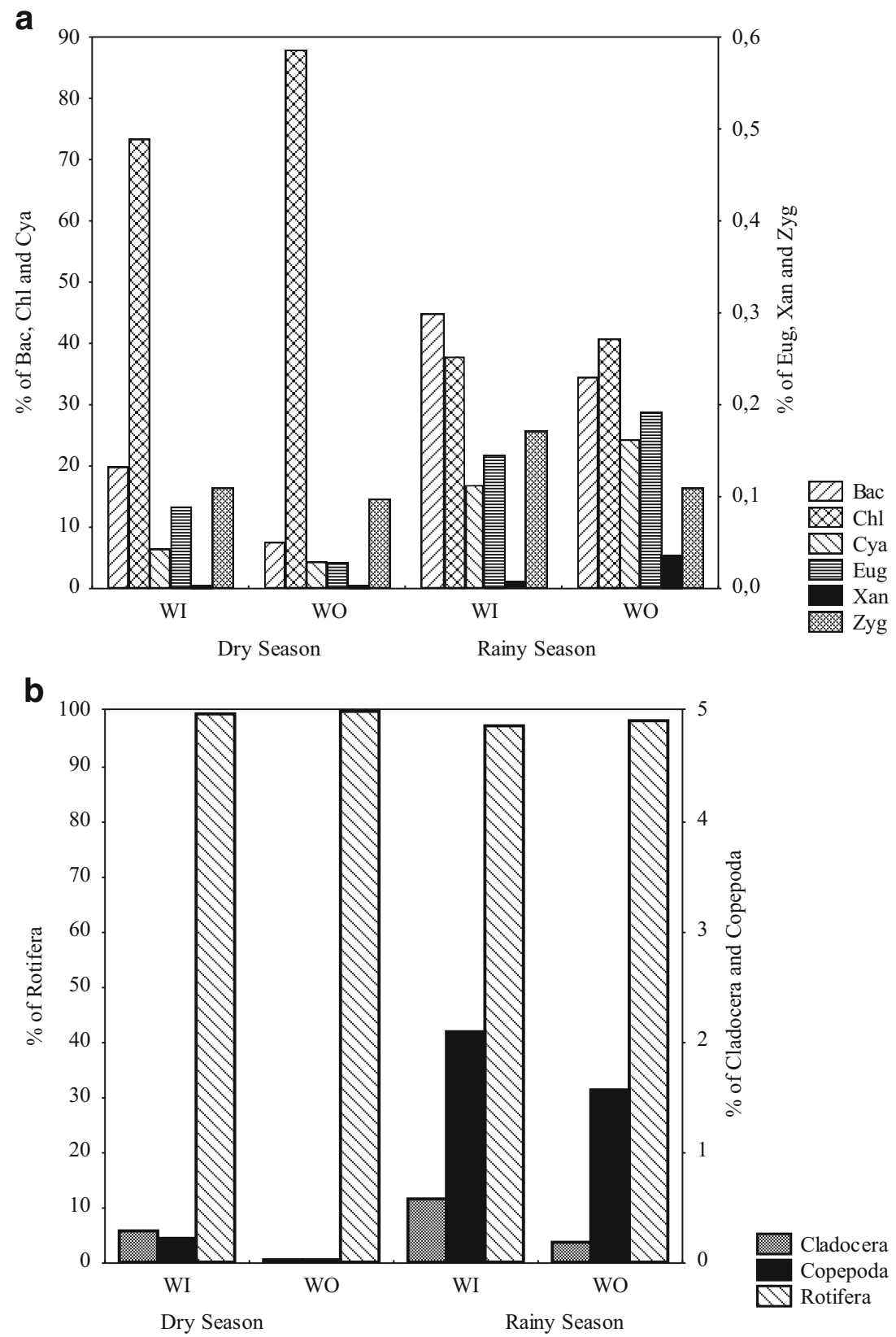

provide advantageous conditions (Warfe and Barmuta 2004). Kuczynska-Kippen (2007) verified that macrophytes with more complicated spatial and morphological structure may offer better concealment conditions and also a more favorable nutritional source compared to morphologically simplified plants, like Typha sp. Among the macrophyte species in our study E. crassipes affords a denser habitat due to the high complexity of roots architecture hanging in the water column. Furthermore, in the dry season the high macrophyte biomass coincided with a decrease of zooplankton richness in the $\mathrm{CW}$ output and with significant differences in zooplankton density between the input and output sampling sites.

Higher HRT favored absorption processes of $\mathrm{N}$ and $\mathrm{P}$ fractions by macrophytes and microorganisms, because the contact time between water, biota and sediment was longer. Other authors also found that removal of $\mathrm{N}$ and $\mathrm{P}$ compounds increases with increasing retention time (Chung et al. 2008; Trang et al. 2010; Dong et al. 2011). Besides nitrogen assimilation into microbial and plant biomass, nitrogen removal in $\mathrm{CW}$ systems occurs through adsorption, ammonia volatilization and coupled nitrification-denitrification, which depend on the environmental conditions within the system. Ammonia volatilization occurs mainly at $\mathrm{pH}$ above 9 (Eighmy and Bishop 1989). The early morning $\mathrm{pH}$ measured in out $\mathrm{CW}$ system ranged between 5.9 and 6.9. However, algal and free-floating photosynthesis increases $\mathrm{pH}$ values during the day, promoting ammonia volatilization in wetlands (Vymazal and Kröpfelová 2008). The higher macrophyte density during 
Table 5 Composition and frequency of zooplankton species in the water inlet (WI) and water outlet (WO), in the dry and rainy seasons

\begin{tabular}{|c|c|c|c|c|}
\hline \multirow[t]{2}{*}{ Taxa } & \multicolumn{2}{|c|}{ Dry } & \multicolumn{2}{|c|}{ Rainy } \\
\hline & WI & WO & WI & $\mathrm{W}$ \\
\hline \multicolumn{5}{|l|}{ Cladocera } \\
\hline Alona monacantha (Sars, 1901) & + & - & - & - \\
\hline Bosmina hagmani Stingelin, 1904 & + & - & + & - \\
\hline Bosmina longirostris (O. F. Muller, 1785) & + & - & - & - \\
\hline Diaphanosoma birgei (Korinek, 1981) & + & + & + & + \\
\hline \multicolumn{5}{|l|}{ Copepoda } \\
\hline Argyrodiaptomus furcatus (Sars, 1901) & + & - & + & + \\
\hline nauplii & + & - & + & + \\
\hline Thermocyclops decipiens (Kiefer, 1929) & + & - & + & + \\
\hline nauplii & + & + & + & + \\
\hline \multicolumn{5}{|l|}{ Rotifera } \\
\hline Anuraeopsis fissa (Gosse, 1851) & + & - & - & - \\
\hline Anuraeopsis navícula (Rousselet, 1910) & + & - & A & A \\
\hline Ascomorpha sp. & + & + & + & + \\
\hline Brachionus calyciflorus (Pallas, 1766) & A & + & + & A \\
\hline Brachionus caudatus (Barrois \& Daday, 1894) & $\mathrm{A}$ & + & A & A \\
\hline Brachionus falcatus (Zacharias, 1898) & + & - & A & + \\
\hline Brachionus havanaensis (Rousselet, 1911) & - & - & + & - \\
\hline Brachionus quadridentatus (Hermann, 1783) & - & - & + & - \\
\hline Cephalodella sp. & + & + & - & - \\
\hline Colurella dicentra (Gosse, 1887) & + & + & - & + \\
\hline Epiphanes macrourus (Barrois \& Daday, 1894) & A & + & + & A \\
\hline Epiphanes sp. & + & + & - & + \\
\hline Filinia opoliensis (Zacharias, 1891) & - & - & + & + \\
\hline Gastropus stylifer (Imhof, 1891) & A & A & A & A \\
\hline Hexarthra intermedia (Hauer, 1953) & - & - & + & - \\
\hline Keratella cochlearis (Gosse, 1851) & A & A & + & + \\
\hline Keratella tropica (Apstein, 1907) & A & + & - & + \\
\hline Lecane elsa (Hauer, 1931) & + & - & + & + \\
\hline Lecane lunaris (Ehrb., 1832) & - & - & + & + \\
\hline Lecane proiecta (Hauer, 1956) & + & + & + & + \\
\hline Lecane signifera (Jennings, 1896) & + & - & - & - \\
\hline Philodina sp. & + & + & + & + \\
\hline Polyarthra sp. & A & A & A & A \\
\hline Proales doliaris (Rousselet, 1895) & $\mathrm{A}$ & + & + & A \\
\hline Proales globulifera (Hauer, 1921) & + & - & + & + \\
\hline Proales sp. & A & + & + & + \\
\hline Proalinopsis caudatus (Collins, 1872) & + & + & - & - \\
\hline Synchaeta sp. & A & + & A & A \\
\hline Synchaeta stylata (Wierzejski, 1893) & A & A & + & A \\
\hline Trichocerca longiseta (Schrank, 1802) & A & A & A & A \\
\hline Trichocerca rattus (Muller 1776) & A & A & A & A \\
\hline
\end{tabular}

$+=$ presence; $-=$ absence; $A$ abundant

the dry season, besides having contributed to efficient nutrient uptake, accounted for the higher DO concentration in that

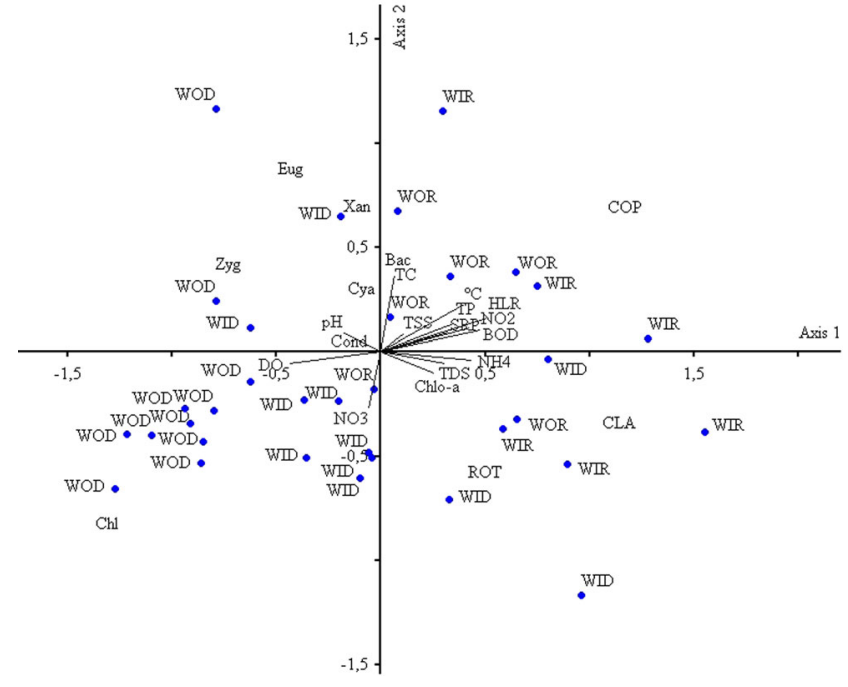

Fig. 4 Bi-plot of the canonical correspondence analysis (CCA) of plankton-environmental factors, where WID $=$ water inlet in the dry season; WIR = water inlet in the rainy season; $\mathrm{WOD}=$ water outlet in the dry season; $\mathrm{WOR}=$ water outlet in the rainy season; $\mathrm{COP}=$ Copepoda; CLA = Cladocera $;$ ROT = Rotifera $;$ Bac = Bacillariophyceae; $\mathrm{Chl}=$ Chlorophyceae; $\mathrm{Cya}=$ Cyanobacteria $; \mathrm{Eug}=$ Euglenophyceae; Xan = Xanthophyceae; Zyg = Zygnemaphyceae

season since macrophytes release oxygen into the rhizosphere and parts of the root system, mainly around the root tips and on young laterals (Armstrong and Armstrong 1990; Wiebner et al. 2002). The increased oxygen availability in the upper layer of the sediment and at oxic microsites in the rhizosphere of macrophytes leads to an enhancement of the nitrification process (Maltais-Landry et al. 2009), which is a prerequisite for denitrification in anoxic zones at the bottom layer of the sediments.

During the rainy season the growth and development of C. giganteus and T. domingensis was impaired by the increasing water depth, due to high rainfall rates. This fact reduces the anchorage capacity of these species by decreasing biomass allocation to rhizomes and roots (Chen et al. 2010). $P$. cordata was not adequate for effluent treatment with high hydraulic loading since it was not capable of surviving until the end of the rainy season. Maine et al. (2006) also reported that this species was not able to survive in $\mathrm{CW}$ treatment systems. The large decrease in plant biomass, specifically of the sub-water parts, restricted the development of the microbial community and the filtering capacity of the substrate in the surface area. The stronger water current and the lower macrophyte biomass increased phytoplankton and zooplankton wash out, resulting in similar densities in the input and output sites. The higher HLR also carried larger amounts of organisms (mainly copepods) from the aquaculture ponds effluents into the $\mathrm{CW}$ system, and hampered the association of zooplankton with macrophyte stands. The high density of copepods in the rainy season (summer) also is related to water temperature (Bozkurt and Guven 2009). 
Fig. 5 Conceptual model of the functioning of the constructed wetland system during the dry (a) and rainy (b) seasons. Size and bold of words indicate relative importance. The darker shading means higher loadings or density of organisms

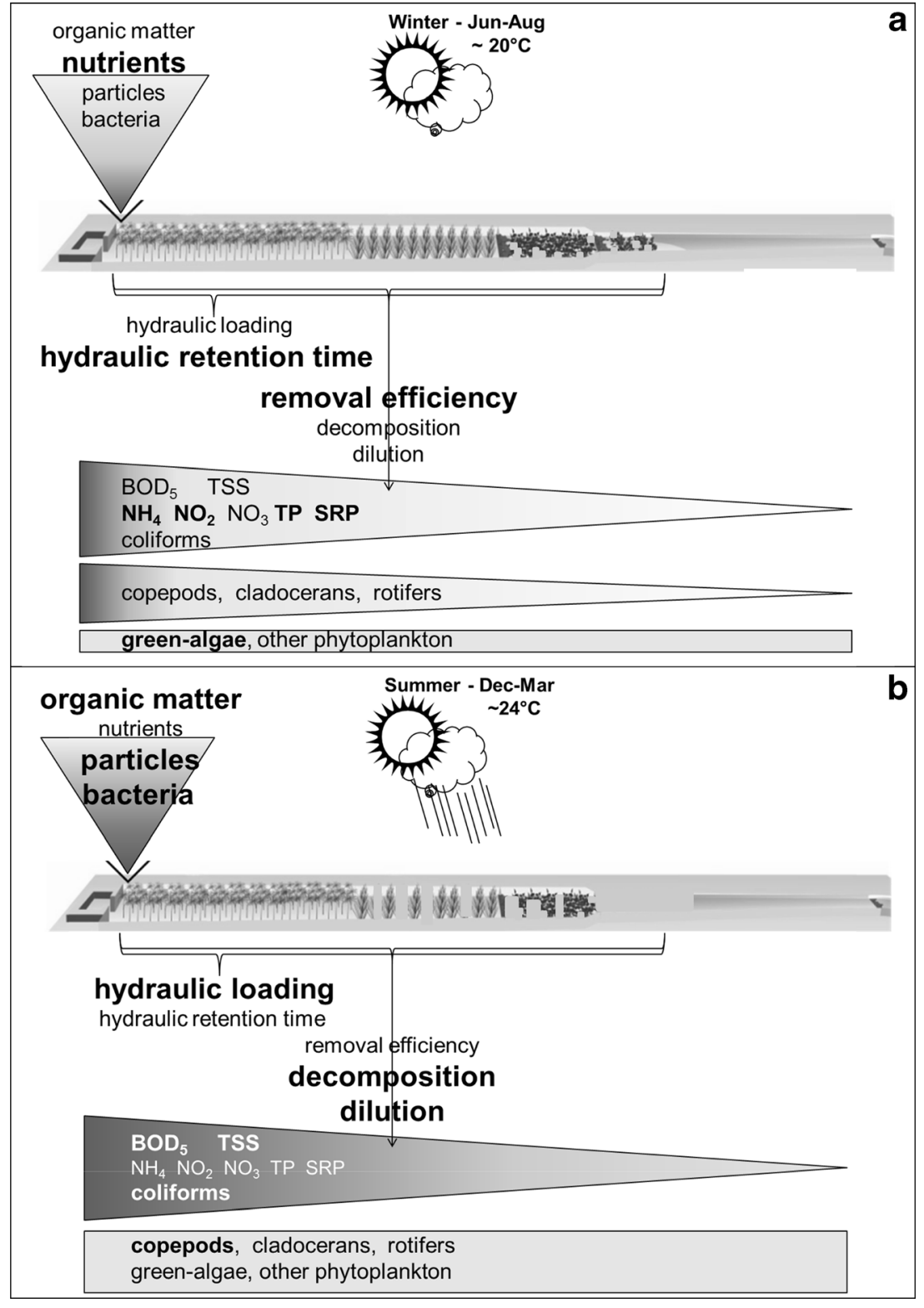

\section{Phytoplankton}

The higher nutrient mass loading in the dry season may account for the high Chlorophyceae density in that season, when the small and non-motile Kirchneriella lunaris was the single dominant species. The genus Kirchneriella can be called rstrategists (Cuvin-Aralar et al. 2004) which in the case of unicellular algae generally are small and present rapid growth when nutrients are abundant (Lampert and Sommer 1997). Because of this, the phytoplankton diversity and evenness were lower in the dry than in the rainy season. Also, the significantly lower Copepoda density entering the CW in the dry season may have contributed to limit phytoplankton diversity during that season; copepods are efficient grazers (as compared to rotifers, Morgan et al. 1980), so that with the lower amount of these grazers, phytoplankton species with competitive advantage like $K$. lunaris could become dominant. Moreover, in accordance with the resource-competitive theory (Tilman 1982), the lowest diversity occurs in places with few limiting resources, as occurred in the dry season.

Species of the genera Melosira generally are more abundant in moderate to high levels of water column turbulence due to their high capacity to adapt to low light intensity and their ability to perennate on sediments. As a consequence of the latter, resuspension of filaments provides a substantial inoculum of live cells to the water column causing growth and population increase (Reynolds et al. 1986). In this study Melosira granulata was abundant in both seasons, but in the rainy season the species Melosira varians also was abundant, due to resuspension of sediment caused by the high HLR. The 
highest abundance of Aulacoseira sp. in the WI site during the dry season and in both sampled sites during the rainy season can also be associated to high water flow (Sherman et al. 1998). Furthermore, the resuspension of the sediment may have increased survival of the thermotolerant coliforms (Katsenovich et al. 2009). Several of the phytoplankton species found in the CW system can potentially be harmful by producing cyanotoxins, such as the genera Microcystis and Nostoc (Prieto et al. 2007). However, neither of these genera were abundant and probably would not affect the other organisms. The Cyanobacteria species Aphanocapsa sp., Chroococcus limneticus and Sphaerocavum brasiliense showed higher densities only during the summer rainy season. The adaptive strategies of some species of Cyanobacteria, such as intense cell division at higher temperatures and the presence of gas vesicles, grant them competitive advantage over other groups of phytoplankton (Reynolds 1984) and eutrophic system conditions favor the establishment of blooms of species of this group (Huszar et al. 2000).

\section{Zooplankton}

In the zooplankton community Rotifera were more abundant than Cladocera and Copepoda in both seasons. The high loading mass of organic matter from the aquaculture ponds and UASB may have resulted in a detrital food chain in which rotifers had a competitive advantage. Bonecker and Aoyagui (2005) verified that generally Rotifera are a major consumer of bacteria mainly when these are at high density, as well as individuals in this group ingest debris particles in which the bacteria may be aggregated. Sipaúba-Tavares et al. (2002), studying the use of the floating macrophyte E. crassipes in constructed wetlands also observed Rotifera as the most abundant group, followed by Cladocera during the dry season and by Copepoda during the rainy one. In general, species with low tolerance of changing environmental conditions are eliminated, while those which can survive in turbulent habitats become dominant. Thus, Rotifera can establish more easily than Cladocera and Copepoda in systems with high hydraulic flow, such as the CW system studied.

\section{Conclusions}

The knowledge generated in this study contributed to the understanding the water regime limitations with regard to biogeochemical processes, removal efficiency of nutrients and organic matter, and performance of macrophyte species in constructed wetland systems in a subtropical climatic region, and thus to improve treatment efficiency. Higher macrophyte biomass, oxygenation, nutrient mass loading rates and hydraulic retention time in the winter dry season lead to better removal efficiency rates. In the summer rainy season the high rate of hydraulic load, temperature, higher inlet organic compounds mass loading and consequent decomposition process and decrease of oxygen concentrations impaired the $\mathrm{CW}$ treatment efficiency. Above all, the main factor for higher removal efficiency in the dry than in the rainy season was the highest biomass macrophytes, due to the direct and indirect effects on the improvement of water quality. The abundance of the zooplankton community changed due to the variation of climatic periods. The dominance and abundance of $r$-strategist planktonic species in the dry season was mainly related to higher nutrient levels. Thereby, the presence of plankton in association with macrophytes and other microorganisms adhered to the substrates should have influenced the removal of chemical compounds in the CW system. The authors suggest the need for interventions, such as engineering modifications to decrease the rate of hydraulic load especially in periods of high precipitation, in order to increase the removal efficiency of nutrients and organic matter by constructed wetlands in subtropical systems.

Acknowledgments The authors would like to thank the São Paulo State Research Foundation - FAPESP (2008/56621-5 and 2010/504786 ) for its financial support. Thanks are also due to the working group of the Limnology and Plankton Production Laboratory, to Marcio Jesus Gonçalves and Mauro Marcelino for their aid in making and maintaining the CW system.

\section{References}

Armstrong J, Armstrong W (1990) Light-enhanced convective throughflow increases oxygenation in rhizomes and rhizosphere of Phragmites-australis (cav.) Trin ex. Steud. The New Phytologist 114:121-128

Baptista JDC, Davenport RJ, Donnelly T, Curtis TP, Rayne D (2008) The microbial diversity of laboratory scale wetlands appears to be randomly assembled. Water Research 42(12):3182-3190

Bobbink R, Beltman B, Verhoeven JTA, Whigham DF (2008) Wetland functioning in relation to biodiversity conservation and restoration. In: Bobbink R, Beltman B, Verhoeven JTA, Whigham DF (eds) Wetlands: functioning, biodiversity, conservation and restoration. Springer-Verlag, Berlin

Bonecker CC, Aoyagui ASM (2005) Relationships between rotifers, phytoplankton and bacterioplankton in the Corumba reservoir, Goiás State, Brazil. Hydrobiologia 546:415-421

Boutilier L, Jamieson R, Gordon R, Lake C, Hart W (2009) Adsorption, sedimentation, and inactivation of $E$. coli within wastewater treatment wetlands. Water Research 43:4370-4380

Boyd CE, Tucker CS (1992) Water quality and pond soil analyses for aquaculture. Agricultural Experiment Station, Alabama

Bozkurt A, Guven SE (2009) Zooplankton composition and distribution in vegetated and unvegetated area of three reservoirs in Hatay, Turkey. Journal of Animal and Veterinary Advances 8(5):984-994

Chen HJ, Zamorano MF, Ivanoff D (2010) Effect of flooding depth on growth, biomass, photosynthesis, and chlorophyll fluorescence of Typha domingensis. Wetlands 30:957-965

Chung AKC, Wu Y, Tam NFY, Wong MH (2008) Nitrogen and phosphate mass balance in a sub-surface flow constructed wetland for treating municipal wastewater. Ecological Engineering 32:81-89 
Cuvin-Aralar ML, Focken U, Becker K, Aralar EV (2004) Effects of low nitrogen-phosphorus ratios in the phytoplankton community in Laguna de Bay, a shallow eutrophic lake in the Philippines. Aquatic Ecology 38(3):387-401

Dong Y, Wilinski PR, Dzakpasu M, Scholz M (2011) Impact of hydraulic loading rate and season on water contaminant reductions within integrated constructed wetlands. Wetlands 31:499-509

Eighmy TT, Bishop PL (1989) Distribution and role of bacterial nitrifying populations in nitrogen removal in aquatic treatment systems. Water Research 23(8):947-955

Ellery WN, Mccarthy TS, Smith ND (2003) Vegetation, hydrology and sedimentation patterns on the major distributary system of the Okavango Fan, Botswana. Wetlands 23(2):357-375

Golterman HL, Clymo RS, Ohnstad MAM (1978) Methods for physical and chemical analysis of freshwater. Blackwell, London

Greenberg AE, Clesceri LS, Eaton AD (1992) Standard methods for examination of water and wastewater. American Public Health Association, Washington

Hadad HR, Maine MA, Bonetto CA (2006) Macrophyte growth in a pilot-scale constructed wetland for industrial wastewater treatment. Chemosphere 63(10):1744-1753

Henry-Silva GG, Camargo AFM, Pezzato MM (2008) Growth of freefloating aquatic macrophytes in different concentrations of nutrients. Hydrobiology 610:153-160

Huszar VLM, Silva LHS, Marinho M, Domingos P, Sant'Anna CL (2000) Cyanoprokaryote assemblages in eight productive tropical Brazilian waters. In: Reynolds CS, Dokulil M, Padisák J (eds) The trophic spectrum revisited: The influence of trophic state on the assembly of phytoplankton communities. Academic Publishers, Dordrecht, pp. 67-77

Izaguirre I, Sinistro R, O'Farrell I, Unrein F, Tell G (2001) Algal assemblages in anoxic relictual oxbow lakes from the Lower Paraná floodplain (Argentina). Nova Hedwigia 123:95-106

Izaguirre I, O'Farrell I, Unrein F, Sinistro R, Afonso MD, Tell G (2004) Algal assemblages across a wetland, from a shallow lake to relictual oxbow lakes (Lower Parana River, South America). Hydrobiologia 511:25-36

Jeppesen E, Lauridsen TL, Kairesalo T, Perrow MR (1998) Impact of submerged macrophytes on fish-zooplankton interactions in lakes. In: Jeppesen E, Sønderaard M, Sondergaard M, Christoffersen K (eds) The structuring role of submerged macrophytes in lakes. Springer, New York, pp. 91-114

Kadlec RH (1999) Chemical, physical and biological cycles in treatment wetlands. Water Science and Technology 40:37-44

Kadlec RH, Wallace SD (2009) Treatment wetlands. Taylor and Francis, Boca Raton

Kaplan D, Bachelin M, Muñoz-Carpena R, Chacón WR (2011) Hydrological importance and water quality treatment potential of a small freshwater wetland in the humid tropics of Costa Rica. Wetlands 31:1117-1130

Karathanasis AD, Potter CL, Coyne MS (2003) Vegetation effects on fecal bacteria, BOD, and suspended solid removal in constructed wetlands treating domestic wastewater. Ecological Engineering 20:157-169

Katsenovich YP, Hummel-Batista A, Ravinet AJ, Miller JF (2009) Performance evaluation of constructed wetlands in a tropical region. Ecological Engineering 35:1529-1537

Kim JG, Rejmankova E, Spanglet HJ (2001) Implications of a sediment chemistry study on subalpine marsh conservation in the lake Tahoe Basin, USA. Wetlands 21(3):379-394

Kim DG, Park J, Lee D, Kang H (2011) Removal of nitrogen and phosphorus from effluent of a secondary wastewater treatment plant using a pond-marsh wetland system. Water, Air, and Soil Pollution 214:37-47

Koroleff F (1976) Determination of ammonia. In: Grasshoff K, Almgreen $\mathrm{T}$ (eds) Methods of seawater analysis. Verlag Chemie, New York, pp. $126-133$
Kuczynska-Kippen N (2007) Habitat choice in rotifera communities of three shallow lakes: impact of macrophyte substratum and season. Hydrobiologia 593:27-37

Lampert W, Sommer U (1997) Limnoecology. The ecology of lakes and streams. Oxford University Press, New York

Lansac-Tôha FA, Velho LFM, Bonecker CC (2003) Influência de macrófitas aquáticas sobre a estrutura da comunidade zooplanctônica. In: Thomaz SM, Bini LM (eds) Ecologia e manejo de macrófitas aquáticas. Maringá, Eduem, pp. 231-242

Li L, Li Y, Biswas DK, Nian Y, Jiang G (2008) Potential of constructed wetlands in treating the eutrophic water: evidence from Taihu Lake of China. Bioresource Technology 99:1656-1663

Lobo E, Leighton G (1986) Estructuras comunitarias de las fitocenosis planctonicas de los sistemas de desembocaduras de ríos y esteros de la zona central de Chile. Revista de Biología Marina y Oceanografía 22(1):1-29

Lund JW, Kiplind C, Lecren ED (1958) The inverted microscope method of estimating algal number and the statistical basis of estimating by counting. Hydrobiologia 11:143-170

Maine MA, Suñe N, Hadad H, Sánchez G, Bonetto C (2006) Nutrient and metal removal in a constructed wetland for wastewater treatment from a metallurgic industry. Ecological Engineering 26:341-347

Maltais-Landry G, Maranger R, Brisson J, Chazarenc F (2009) Nitrogen transformations and retention in planted and artificially aerated constructed wetlands. Water Research 43:535-545

Mann CJ, Wetzel RG (2000) Hydrology of impounded lotic wetlandwetland sediment characteristics. Wetlands 20(1):23-32

McCune B, Mefford MJ (2006) PC-ORD. Multivariate Analysis of Ecological Data. Version 5.15

Mitsch WJ, Gosselink JG (2000) Wetlands. Wiley, New York

Morgan NC, Backiel T, Bretschko G, Dunkan A, Hillbricht-Ilkowska A, Kajak Z, Kitchell JF, Larsson P, Leveque C, Nauwerck A, Schiemer F, Thorpe JE (1980) Secondary production. In: LeCren ED, LoweMcConnell RH (eds) The functioning of freshwater ecosystems, International Biological Program v. 22. Cambridge University Press, Cambridge, pp. 247-340

Norlin JI, Bayley SE, Ross LCM (2005) Submerged macrophytes, zooplankton and the predominance of low-over high-chlorophyll states in western boreal shallow-water wetlands. Freshwater Biology 50: 868-881

Nusch EA (1980) Comparison of different method for chlorophyll and pheopigments determination. Archiv für Hydrobiologie 14:14-36

O'Farrell I, Sinistro R, Izaguirre I, Unrein F (2003) Do steady state assemblages occur in shallow lentic environments from wetlands? Hydrobiologia 502:197-209

Pielou EC (1975) Ecological diversity. Wiley, New York, 165p

Prieto AI, Pichardo S, Jos A, Moreno I, Camean AM (2007) Timedependent oxidative stress responses after acute exposure to toxic cyanobacterial cells containing microcystins in tilapia fish (Oreochromis niloticus) under laboratory conditions. Aquatic Toxicology 84:337-345

Reynolds CS (1984) Phytoplankton periodicity: the interactions of form, function and environmental variability. Freshwater Biology 14:111-142

Reynolds CS, Montecino V, Graf ME, Cabrera S (1986) Short-term dynamics of a Melosira population in the plankton of an impoundment in Central Chile. Journal of Plankton Research 8:715-740

Sherman BS, Webster IT, Jones GJ, Oliver RL (1998) Transition between Aulacoseira and Anabaena dominance in a turbid river weir pool. Limnology and Oceanography 43:1902-1915

Sinistro R, Izaguirre I, Asikian V (2006) Experimental study on the microbial plankton community in a South American wetland (Lower Paraná River Basin) and the effect of the light deficiency due to the floating macrophytes. Journal of Plankton Research 28(8):753-768

Sipaúba-Tavares LH, Favero EGP, Braga FMS (2002) Utilization of macrophyte biofilter in effluent from aquaculture: I. Floating plant. Brazilian Journal of Biology 62(4-a):713-723 
StatSoft Inc (2007) Statistica: Data analysis software system, version 8.0. Available from <www.statsoft.com $>$

ter Braak C (1988) CANOCO - A FORTRAN Program for Canonical Community Ordination. Ministerie van Landbouw en Visserij. Groep Landbouwwiskunde, Wageningen, 95 pp

Thomaz SM, Cunha ER (2010) The role of macrophytes in habitat structuring in aquatic ecosystems: methods of measurement, causes and consequences on animal assemblages' composition and biodiversity. Acta Limnologica Brasiliensia 22(2):218-236

Tilman D (1982) Resource competition and community structure. Princeton University Press, Princeton

Trang NTD, Konnerup D, Schierup HH, Chiem NH, Tuan LA, Brix H (2010) Kinetics of pollutant removal from domestic wastewater in a tropical horizontal subsurface flow constructed wetland system: effects of hydraulic loading rate. Ecological Engineering 36(4):527-535

Travaini-Lima F, Sipaúba-Tavares LH (2012) Efficiency of a constructed wetland for wastewaters treatment. Acta Limnologica Brasiliensia 24(3):255-265
Truu J, Nurk K, Juhanson J, Mander Ü (2005) Variation of microbiological parameters within planted soil filter for domestic wastewater treatment. Journal of Environmental Health 40:1191-1200

Utermöhl H (1958) Zur Vervollkommung der quantitativen phytoplankton: methodik. Mitteilungen Internationale Vereinigung fur Theoretische und Angewandte Limnologie 9:1-38

Van Donk E, Van de Bund W (2002) Impact of submerged macrophytes including charophytes on phyto- and zooplankton communities: allelopathy versus other mechanisms. Aquatic Botany 72:261-274

Vymazal J, Kröpfelová L (2008) Wastewater treatment in constructed wetlands with horizontal sub-surface flow. Springer, Dordrecht

Warfe DM, Barmuta LA (2004) Habitat structural complexity mediates the foraging success of multiple predator species. Oecologia 141: $171-178$

Wiebner A, Kuschk PK, Astner M, Stottmeister U (2002) Abilities of helophyte species to release oxygen into rhizosphere with varying redox conditions in laboratory-scale hydroponic systems. International Journal of Phytoremediation 1:1-15 